\title{
Retropharyngeal Abscess
}

National Cancer Institute

\section{Source}

National Cancer Institute. Retropharyngeal Abscess. NCI Thesaurus. Code C128324.

An abscess that develops in the soft tissues behind the posterior pharyngeal wall. 